\title{
Serum agonistic autoantibodies against type-1 angiotensin II receptor titer in patients with epithelial ovarian cancer: a potential role in tumor cell migration and angiogenesis
}

\author{
Li Song, Su-Li Zhang, Ke-Hua Bai, Jie Yang, Hai-Yan Xiong, Xiao Li, Teng Liu and Hui-Rong Liu*
}

\begin{abstract}
Background: Although agonistic autoantibodies against type-1 angiotensin-II receptor (AT $1-A A$ ) are frequently detected in women with preeclampsia, the clinical significance of $\mathrm{AT}_{1}-\mathrm{AA}$ in association with epithelial ovarian cancer (EOC) has not been identified.

Methods: In an attempt to clarify this issue, we measured serum AT 1 -AA titer from EOC patients $(n=89)$ and healthy normal subjects $(n=55)$, correlated $A T_{1}$-AA titer with EOC stage and grade, and demonstrated the effects of purified $A T_{1}-A A$ on migration of ovarian cancer cells and angiogenesis of chick embryo chorioallantoic membrane.

Results: We found that the $\mathrm{AT}_{1}-\mathrm{AA}$ titer was significantly higher in EOC patients compared with healthy control subjects $(1.77 \pm 0.28$ vs. $0.35 \pm 0.05, P<0.01)$. The positive rate was averaged by $72.1 \pm 2.5 \%$ in EOC patients and $15.5 \pm 1.5 \%$ in control $(P<0.01)$. Increased $\mathrm{AT}_{1}$-AA titer in EOC patients was associated with advanced stages and grades of EOC, and positively correlated with level of vascular endothelial growth factor $(r=0.855, P<0.01)$. Furthermore, $\mathrm{AT}_{1}$-AA directly stimulated migration of ovarian cancer cells and enhanced microvascular density of chick embryo chorioallantoic membrane. These $\mathrm{AT}_{1}$-AA-mediated effects were significantly blocked either by an autoantibody-neutralizing peptide or an angiotensin II type I receptor antagonist, losartan.

Conclusion: Taken together, we found that a higher serum AT 1 -AA titer may be associated with advanced progression of EOC in patients and play an important role in development of EOC by promoting cancer cell migration and angiogenesis. These findings implicate that $\mathrm{AT}_{1}$-AA might be selected as a detectable biomarker and potential therapeutic target in diagnosis and treatment of EOC patients.
\end{abstract}

Keywords: Angiotensin || type I receptor, Autoantibodies against type-1 angiotensin || receptor, Angiogenesis, Epithelial ovarian cancer

\section{Background}

Epithelial ovarian cancer (EOC) is the sixth most common cancer and the seventh cause of death worldwide among women who develop gynecological cancer [1], with the estimated 22,280 new cases and 15,500 deaths in the United States in 2012. The vast majority of EOC patients are usually diagnosed with advanced stages due to the lack of adequate early screening tests and early specific symptoms during development of EOC [2]. The

\footnotetext{
* Correspondence: liuhr2000@126.com

Department of Pathophysiology, Capital Medical University, Beijing, P.R. China
}

(c) 2013 Song et al.; licensee BioMed Central Ltd. This is an Open Access article distributed under the terms of the Creative Commons Attribution License (http://creativecommons.org/licenses/by/2.0), which permits unrestricted use, distribution, and reproduction in any medium, provided the original work is properly cited. debulking surgery followed by platinum-taxane based chemotherapy. These patients, however, are also at great risk of recurrence and emerging drug resistance with a more than $70 \%$ of relapse rate and a mean 18 months of progression-free survival period $[2,3]$. Therefore, understanding the pathogenesis of EOC and identifying early detectable biomarkers are essential to improve overall survival rate in advanced EOC patient.

It has well been defined that angiotensin II (Ang II) derived from the activated renin-angiotensin system plays a key role in the regulation of cardiovascular 
homeostasis through its two receptors: Ang II type 1 $\left(\mathrm{AT}_{1}\right)$ and type $2\left(\mathrm{AT}_{2}\right)$ receptors, which maintain arterial blood pressure, fluid and electrolyte homeostasis. Through the $\mathrm{AT}_{2}$ receptor, Ang II evokes vasodilatation, sodium excretion and blood pressure reduction, and thereby counteracts the effects of $\mathrm{AT}_{1}$ receptor [4]. However, increasing evidence suggests that Ang II is also involved in tumor cell migration/invasion, angiogenesis and metastasis through $\mathrm{AT}_{1}$ receptor during the tumor development [5-7]. In patient with EOC, it has previously been reported that Ang II enhances vascular endothelial growth factor (VEGF) secretion, angiogenesis and tumor cell invasion via up-regulating G-protein-coupled $\mathrm{AT}_{1}$ receptor; importantly, angiogenesis and peritoneal dissemination of the EOC can selectively be blocked using $\mathrm{AT}_{1}$ receptor antagonist $[6,8]$. Therefore, considerable effort has been placed on the development of Ang II blockade therapy as a new strategy for EOC treatment.

Recent studies have demonstrated that agonistic autoantibodies against type- 1 angiotensin II receptor $\left(\mathrm{AT}_{1^{-}}\right.$ AA) detected in preeclampsia induces significant placental trophoblast invasion [9], suggesting that $\mathrm{AT}_{1}-\mathrm{AA}$ is one of the potential causative factors in development of preeclampsia. We have previously reported that $\mathrm{AT}_{1}$-AA constricts human fetoplacental blood vessels and restricts fetal perfusion through activating Ang II $\mathrm{AT}_{1}$ receptor [10]. Although animals studies have shown that activation of $\mathrm{AT}_{1}$-AA is associated with elevation of intracellular $\mathrm{Ca}^{2+}$ in vascular smooth muscle cells [11], stimulation of placental and vascular NADPH oxidase [12] and activation of NF- $\mathrm{KB}$ [13], all of which may cause inflammation and contribute to pathogenesis of preeclampsia via $\mathrm{AT}_{1}-\mathrm{AA}$, there is less specific data to show whether $\mathrm{AT}_{1}-\mathrm{AA}$ is elevated in patient with EOC and correlated with the advanced progression of EOC. Therefore, in the current study, we examined the serum $\mathrm{AT}_{1}-\mathrm{AA}$ titer in $\mathrm{EOC}$ patients and determined whether change in $\mathrm{AT}_{1}$ - $\mathrm{AA}$ level is associated with malignant grades and angiogenic factor, VEGF. Using $\mathrm{AT}_{1}$-AA purified from EOC patients, we demonstrated the effects of $\mathrm{AT}_{1}$ - $\mathrm{AA}$ on migration of ovarian cancer cells and microvascular density of chick embryo chorioallantoic membrane. Furthermore, we investigated whether the $\mathrm{AT}_{1}$-AA-elicited biological effects could be suppressed by autoantibody-neutralizing $\mathrm{AT}_{1}$-AA peptide, and whether cell migration and angiogenesis stimulated by $\mathrm{AT}_{1}-\mathrm{AA}$ could be blocked by Ang II $\mathrm{AT}_{1}$ receptor antagonist.

\section{Methods}

\section{Patients}

The study included 89 malignant EOC patients who were diagnosed and operated in the third hospital of Capital Medical University during the period of 05/2010 to $04 / 2012$. Cases were chosen based on the histological grades and clinical stages of EOC patients according to the International Federation of Gynecology and Obstetrics (FIGO) criteria. The healthy control subjects $(\mathrm{n}=55)$ were enrolled from laparoscopy-negative cases on the clinical assessment at the same hospital. No significant difference in age was found between these two groups. The consent form was signed by all patients and the research protocol was approved by the Institutional Committee for the Protection of Human Subjects of Capital Medical University. Cases were excluded if patients were associated with 1) autoimmune diseases and endocrinal diseases; 2) complications derived from other different organ systems; 3) immune deficiencies diseases; 4) significant gastrointestinal diseases. All clinical and laboratory data were recorded. Serum samples were collected from the patients in both groups and stored at $-80^{\circ} \mathrm{C}$ until use.

\section{Measurement of $\mathrm{AT}_{1}-\mathrm{AA}$ titer and VEGF by enzyme-linked immunosorbent assay (ELISA)}

The serum $\mathrm{AT}_{1}$-AA level in patients was detected by ELISA as we reported previously [10]. Briefly, 96-well microtiter plates were coated with $1 \mu \mathrm{g} / \mathrm{ml} \mathrm{AT}_{1} \mathrm{R}$-ECII peptide synthesized from patients (GL Biochem Ltd, Shanghai, China) and incubated overnight at $4^{\circ} \mathrm{C}$. After washing the plates with PBS three times, $50 \mu \mathrm{l}$ serum samples were added to the plates and incubated at $37^{\circ} \mathrm{C}$ for $1 \mathrm{~h}$. The biotinylated goat anti-human IgG antibody (1:3,000, Zhongshan Inc., Beijing, China) or streptavidinperoxidase conjugate $(1: 2,000$ Vector, CA, USA) was then incubated separately at $37^{\circ} \mathrm{C}$ for $1 \mathrm{~h}$ during washings. Finally, 2, 2-azino-di (3-ethylbenzothiazoline) sulphonic acid (ABTS) $-\mathrm{H}_{2} \mathrm{O}_{2}$ (Roche, Basel, Switzerland) substrate buffer was applied for a half hour before reading. The optical densities (OD) from these plates were measured at $405 \mathrm{~nm}$ in a plate reader (Molecular Devices Corp, CA, USA). The $\mathrm{AT}_{1}$-AA titer was expressed as the ratio of positive/negative $(\mathrm{P} / \mathrm{N})$, i.e., (the $\mathrm{OD}$ of specimen - the $\mathrm{OD}$ of blank control) / (the OD of negative control - the OD of blank control). The positivity of the serum sample to $\mathrm{AT}_{1}$-AA was defined as $P / N \geq 2.1$, while the negativity was defined as $\mathrm{P} / \mathrm{N} \leq 1.5$. All assays were performed in duplicate. Commercially accessible ELISA kit (DaKeWe Biotechnological Corp, Shengzheng, China) were used to determine the patients' serum VEGF level according to the manufacturer's instructions. VEGF concentration was expressed as ng/L and the assays were performed in duplicate.

\section{$\mathrm{AT}_{1}$-AA peptide synthesis}

$\mathrm{AT}_{1}$-AA peptide fragments equivalent to the sequence of human anti- $\mathrm{AT}_{1}$ receptor antibody $\left(\mathrm{AT}_{1} \mathrm{R}\right.$-ECII, 165191, I-H-R-N-V-F-F-I-I-N-T-N-I-T-V-C-A-F-H-Y-E-S-Q$\mathrm{N}-\mathrm{S}-\mathrm{T}-\mathrm{L}$ ) was synthesized by solid-phase peptide synthesis method (GL Biochem Ltd, Shanghai, China). The purity of synthetic peptide was confirmed with a high pressure liquid chromatography as we reported previously [10]. 


\section{Purification of the immunoglobulin $\mathrm{G}$ fraction}

The total immunoglobulin $G$ was isolated from serum samples with $\mathrm{AT}_{1}-\mathrm{AA}$ positive $\mathrm{EOC}$ patients or $\mathrm{AT}_{1}-\mathrm{AA}$ negative healthy normal subjects by Mab Trap Kit (Amersham, NJ, USA). The purities of extractions were assessed by sodium dodecylsulfonate-polyacrylate gel electrophoresis (SDS-PAGE) as we reported previously [10].

\section{Cell lines and cell migration assay}

Human ovarian cancer cells (OVCAR3) were purchased from the Cancer Hospital of Chinese Academy of Medical Sciences, Beijing, China and maintained in DMEM supplemented with $10 \% \mathrm{FBS}, 2 \mathrm{mM}$ l-glutamine, 100 units $/ \mathrm{ml}$ penicillin and $100 \mu \mathrm{g} / \mathrm{ml}$ streptomycin. For all experiments, cells were detached with $0.25 \%$ trypsin and $0.02 \%$ EDTA and washed once in complete medium before use. Migration assay was conducted according to the manufacture's recommended protocol (BD Biosciences, New Jersey, USA). Briefly, OVCAR3 at $5 \times 10^{4}$ concentration were suspended in $300 \mu \mathrm{l}$ of serum free media in the upper chamber with pre-coated filters (6.5 $\mathrm{mm}$ in diameter and $8 \mu \mathrm{m}$ pore-size) with or without $\mathrm{AT}_{1}$-AA, Ang II, $\mathrm{AT}_{1} \mathrm{R}$-ECII or Ang II $\mathrm{AT}_{1}$ receptor antagonist, losartan. Bottom chambers were filled with medium containing 10\% FBS as a chemoattractant. After cells were allowed to seed on the chambers for $24 \mathrm{~h}$ at $37^{\circ} \mathrm{C}$, cells on the upper chamber and migrated cells at the bottom chamber were wiped with a cotton swab and then mixed with staining solution containing $0.125 \%$ coomassie blue in a mixture of methanol, acetic acid and water in a ratio of 45:10:45. The results were visualized under an inverted microscope from 5 randomized high power fields $(x 400)$. Results were calculated from the average of 3 separate assays conducted in triplicate.

\section{Visualization of microvascular density in chick embryo chorioallantoic membrane (CAM)}

Fertilized white leghorn chicken eggs were received at day 0 and incubated for 3 days at $37^{\circ} \mathrm{C}$ with constant humidity. On day 3 , eggs were rinsed with $70 \%$ ethanol and a square window $\left(0.5 \mathrm{~cm}^{2}\right)$ was made with a pair of sterile scissor and cut away a circle of shell, thus exposing the underlying membrane (the chorioallantois). After the eggs $\left(n=8 /\right.$ each group) were treated with saline, $\mathrm{AT}_{1^{-}}$ $\mathrm{AA}$, Ang II, $\mathrm{AT}_{1} \mathrm{R}$-ECII or losartan, respectively for $30 \mathrm{~min}$, the window was sealed with transparent tape and the eggs returned to the incubator at $90 \%$ relative humidity without turning. After $72 \mathrm{~h}$ of incubation, the CAM was fixed using $3.7 \%$ formaldehyde for $15 \mathrm{~min}$, cut $3 \mathrm{~cm}^{2}$ from the center and mounted on the slides for observation. The angiogenic results were visualized on an inverted microscope from 5 randomized fields. For each experiment, the staggered images were digitized and results were calculated as a mean of microvascular density per high power field ( $\mathrm{x} 400)$.

\section{Statistical analysis}

All data were calculated as mean \pm SE. Statistical analysis was performed with SPSS 15.0 software. The positive rates in the two groups were compared with chi-square test. The $t$-test was applied for comparing two independent sample means, and the one-way ANOVA was used for comparing means of more than two samples. $\mathrm{P}<0.05$ was considered to be statistically significant.

\section{Results}

\section{Clinical characteristics presented in EOC patients}

Patient characteristics, stage and grade are shown in Table 1 . The mean age of the EOC at primary diagnosis was $50.4 \pm 11$ years and the mean history of the EOC was $7.4 \pm 6$ years. The mean age of the EOC at menarche was $15 \pm 2$, and at menopause was $47 \pm 4$. The FIGO stage of EOC patients was classified as follows: I: $6 \%$; II: $56 \%$; III: 23\%; IV: 4\%. Most EOC patients were at the grade III (61\%). Fifty-four patients (28\%) had ascites whereas 31\% patients had no such complication.

\section{Table 1 Patient characteristics}

\begin{tabular}{lc}
\hline Characteristic & Number \\
\hline Age at diagnosis & $51+8.2$ \\
Weight (kg) & $62+8.9$ \\
BMl (kg/m2) & $25+4.1$ \\
Age at menarche & $15+2.0$ \\
Age at menopause & $47+4.2$ \\
Stage & \\
I & $6(6.7 \%)$ \\
II & $56(62.9 \%)$ \\
III & $23(25.8 \%)$ \\
IV & $4(4.4 \%)$ \\
Grade & \\
G1 & $20(22.4 \%)$ \\
G2 & $27(30.3 \%)$ \\
G3 & $42(85.7 \%)$ \\
Residual tumor & \\
$\leq 2 \mathrm{~cm}$ & $18(20.2 \%)$ \\
$>2 \mathrm{~cm}$ & $71(79.7 \%)$ \\
Ascites & \\
No & $31(34.8 \%)$ \\
Yes & $58(65.1 \%)$ \\
Diabetes Status & \\
No & $59(63.7 \%)$ \\
Yes & \\
\hline Valus are & \\
\hline & \\
\hline
\end{tabular}

Values are mean $\pm \mathrm{SE}$; others represent the percentage of total patients. 


\section{Clinical significance of $\mathrm{AT}_{1}-\mathrm{AA}$ titer in EOC patients}

The serum $\mathrm{AT}_{1}$-AA titer in EOC patients and healthy control subjects was measured by ELISA. As shown in Figure $1 \mathrm{~A}$, the serum $\mathrm{AT}_{1}$-AA titer was significantly increased from $0.35 \pm 0.05$ in healthy normal subjects to $1.77 \pm 0.28$ in EOC patients $(\mathrm{P}<0.01)$. The average positive rate of $\mathrm{AT}_{1}-\mathrm{AA}$ in $\mathrm{EOC}$ patients was significantly higher than that in healthy normal subjects $(72.1 \% \pm 2.5 \%$ vs. $15.5 \% \pm 1.9 \%, \mathrm{P}<0.01)$. The correlation of serum $\mathrm{AT}_{1}$ AA with clinicopathological outcomes was analyzed in EOC patients. As shown in Figure 1B, the number of $\mathrm{AT}_{1}$-AA positive patients was increased with clinical FIGO stage: $45 \%$ in stage $1,61.5 \%$ in stage II and $72.8 \%$ in advanced stage III. Moreover, the $\mathrm{AT}_{1}-\mathrm{AA}$ titer was also significantly higher in patients with an advanced grade (Figure 1C): $61.7 \%$ in grade $1,72.7 \%$ in grade II and $80.1 \%$ in grade 3 . These results indicated that $\mathrm{AT}_{1}$-AA level increases with progression of EOC stage and grade.

\section{Correlation between serum $\mathrm{AT}_{1}-\mathrm{AA}$ titer and VEGF}

To determine whether serum $\mathrm{AT}_{1}$-AA titer is associated with angiogenesis of the tumor, we examined the serum level of VEGF by ELISA in the same series of EOC patients. As shown in Figure 2A and 2B, VEGF level was significantly increased in patients with advanced FIGO stage and grade (i.e., at level III) compared with those in an early FIGO stage and grade (i.e., at level I). Positive linear correlation among the serum $\mathrm{AT}_{1}$-AA level and VEGF was detected, (Figure $2 \mathrm{C}, \mathrm{r}^{2}=0.855, \mathrm{p}<0.01$ ), suggesting that $\mathrm{AT}_{1}$ - $\mathrm{AA}$ may play a role in angiogenesis during development of EOC through enhancing VEGF expression.

\section{Effect of $A T_{1}-A A$ on migration of ovarian cancer cells}

OVCAR3 cells derived from the progressive adenocarcinoma of the ovary were used in this study. Migration of OVCAR3 cells stimulated by adding $\mathrm{AT}_{1}$-AA was enhanced in a dose-dependent manner. As shown in the top panel of Figure 3, cell migration rates were consequently increased relative to the control when cells were treated with different dose of $\mathrm{AT}_{1}$-AA $(50,100,200 \mathrm{nM})$ for $24 \mathrm{~h}$. To demonstrate the potency of $\mathrm{AT}_{1}-\mathrm{AA}$ in stimulation of cell migration by activating angiotensin $\mathrm{AT}_{1}$ receptor, OVCAR3 cells were treated either with exogenous $\mathrm{AT}_{1}$-AA $(100 \mathrm{nM})$ or Ang II $(100 \mathrm{nM})$, respectively before subjecting to cell migration. As shown at the bottom panel of Figure 3, both $\mathrm{AT}_{1}$-AA and Ang II produced a comparable level in cell migration. Stimulation by $\mathrm{AT}_{1}$-AA $(100 \mathrm{nM})$ on cell migration was completely blocked either by the $\mathrm{AT}_{1} \mathrm{R}$-ECII $(100 \mathrm{nM})$ or by the selective Ang II AT 1 receptor antagonist, losartan (300 nM), suggesting that $\mathrm{AT}_{1}-\mathrm{AA}$ has direct stimulating effect on tumor cell migration and enhancement of OVCAR3 cell migration by $\mathrm{AT}_{1}$ - $\mathrm{AA}$ is mediated by Ang II $\mathrm{AT}_{1}$ receptor. Addition of losartan or $\mathrm{AT}_{1} \mathrm{R}$-EC II alone had no effect on migration of OVCAR3 cells.

\section{Effect of $A T_{1}-A A$ on angiogenesis of the CAM}

$\mathrm{AT}_{1}$ - $\mathrm{AA}$ administration caused a significant increase in microvascular density in the CAM. Figure 4 shows the representative photographs of $\mathrm{AT}_{1}$-AA-treated and saline control CAM. Quantitatively, in each of the six experiments, the microvascular density of the CAM treated with $\mathrm{AT}_{1}$ - $\mathrm{AA}(100 \mathrm{nM})$ was increased by $60-70 \%$ compared with saline control. Addition of Ang II (100 nM) also increased the microvascular density of the CAM to a comparable level as that found in the $\mathrm{AT}_{1}$ - $\mathrm{AA}$ treated CAM. Enhancement in the microvascular density by $\mathrm{AT}_{1^{-}}$ AA was significantly blocked either by $\mathrm{AT}_{1} \mathrm{R}$-ECII $(100$ $\mathrm{nM})$ or losartan (300 nM), suggesting a role of $\mathrm{AT}_{1}-\mathrm{AA}$ in angiogenesis through stimulating Ang II $\mathrm{AT}_{1}$ receptor. Simultaneous addition of only the $\mathrm{AT}_{1} \mathrm{R}$-ECII $(100 \mathrm{nM})$ or the losartan $(300 \mathrm{nM})$, without $\mathrm{AT}_{1}$-AA or Ang II, did not affect the microvascular density when compared with saline control (Figure 4).

\section{Discussion}

These results are the first to demonstrate that $\mathrm{AT}_{1}$-AA level is significantly elevated in EOC patients. Enhanced $\mathrm{AT}_{1}$-AA titer was associated with advanced stage and grade of the EOC and positively correlated with VEGF
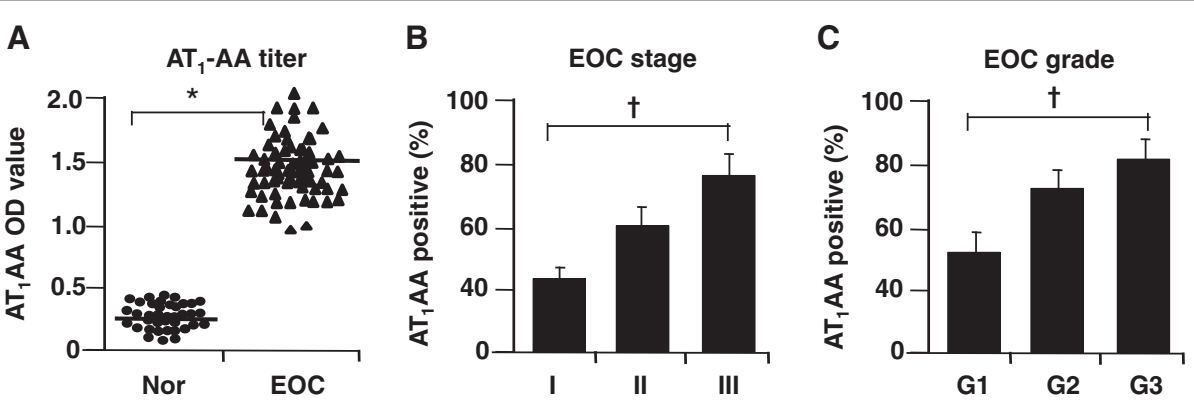

Figure 1 Level of $\mathrm{AT}_{1}-\mathrm{AA}$ in EOC patients. Relative to the healthy normal subjects, $A T_{1}-\mathrm{AA}$ titer was significantly increased in EOC patients (A). The number of $\mathrm{AT}_{1}-\mathrm{AA}$ positive patients was associated with clinical FIGO stage (B) and grade $(\mathbf{C})$. Values are mean $\pm \mathrm{SE}$. ${ }^{*} \mathrm{p}<0.05 \mathrm{vs}$. the normal subjects (Nor); $\mathrm{P}<0.05$ vs. the stage I and grade I, respectively. 

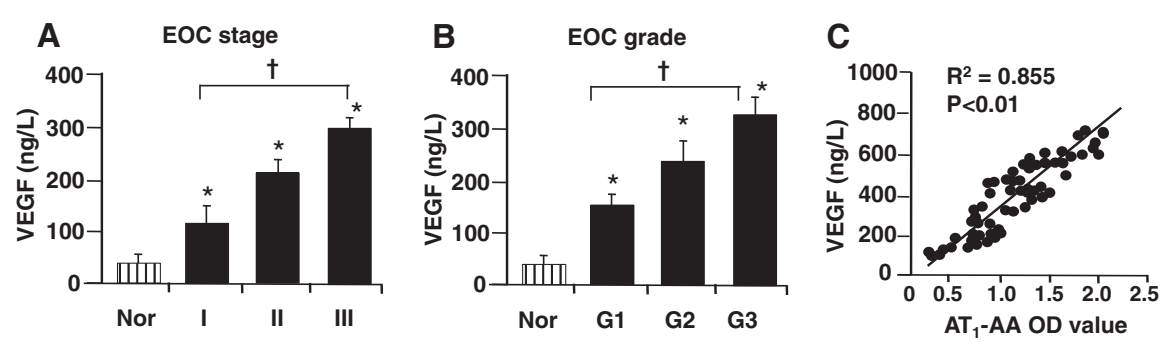

Figure 2 VEGF level in EOC patients and healthy normal subjects. Increased level of VEGF was detected in advanced stage (A) and grade (B). Scatter plots showed a positive linear correlation between VEGF level and $A T_{1}$-AA titer in EOC patients (C). Values are mean \pm SE. ${ }^{*} p<0.05$ vs. the normal subjects (Nor); $\mathrm{P}<0.05$ vs. the stage I and grade I, respectively.

level in patients. Using cultured OVCAR3 cells and the $\mathrm{CAM}$ of chick embryo, we found that $\mathrm{AT}_{1}$ - $\mathrm{AA}$ has direct effect on cell migration and angiogenesis through activating Ang II $\mathrm{AT}_{1}$ receptor.

$\mathrm{AT}_{1}-\mathrm{AA}$, an autoantibody against angiotensin II type 1 receptor, which is characterized to activate the receptor via specifically interacting with the second extracellular loop of the Ang II $\mathrm{AT}_{1}$ receptor, has been documented to play a role in the pathogenesis of preeclampsia and hypertension $[10,11,13-15]$. However, $\mathrm{AT}_{1}$-AA level and function has not been examined or identified in the ovarian cancer. In the current study, we found that serum titer and positive rate of $\mathrm{AT}_{1}$-AA were significantly increased in EOC patients. More importantly, this study revealed that the level of $\mathrm{AT}_{1}-\mathrm{AA}$ is significantly elevated with an advanced FGIO stage and grade in EOC patients, supporting the concept that $\mathrm{AT}_{1}$ - $\mathrm{AA}$ may participate in ovarian cancer development and progression. As it has well been demonstrated, the FIGO stage and grade are poor prognostic factors for overall survival in EOC patients [3]. Therefore, monitoring serum $\mathrm{AT}_{1}$-AA level might be of great value as a single marker in detecting all stages of EOC patients for clinical screening test, diagnosis and prognosis after therapeutic intervention.

VEGF is a main angiogenic factor in development of ovarian cancer through promoting angiogenesis and
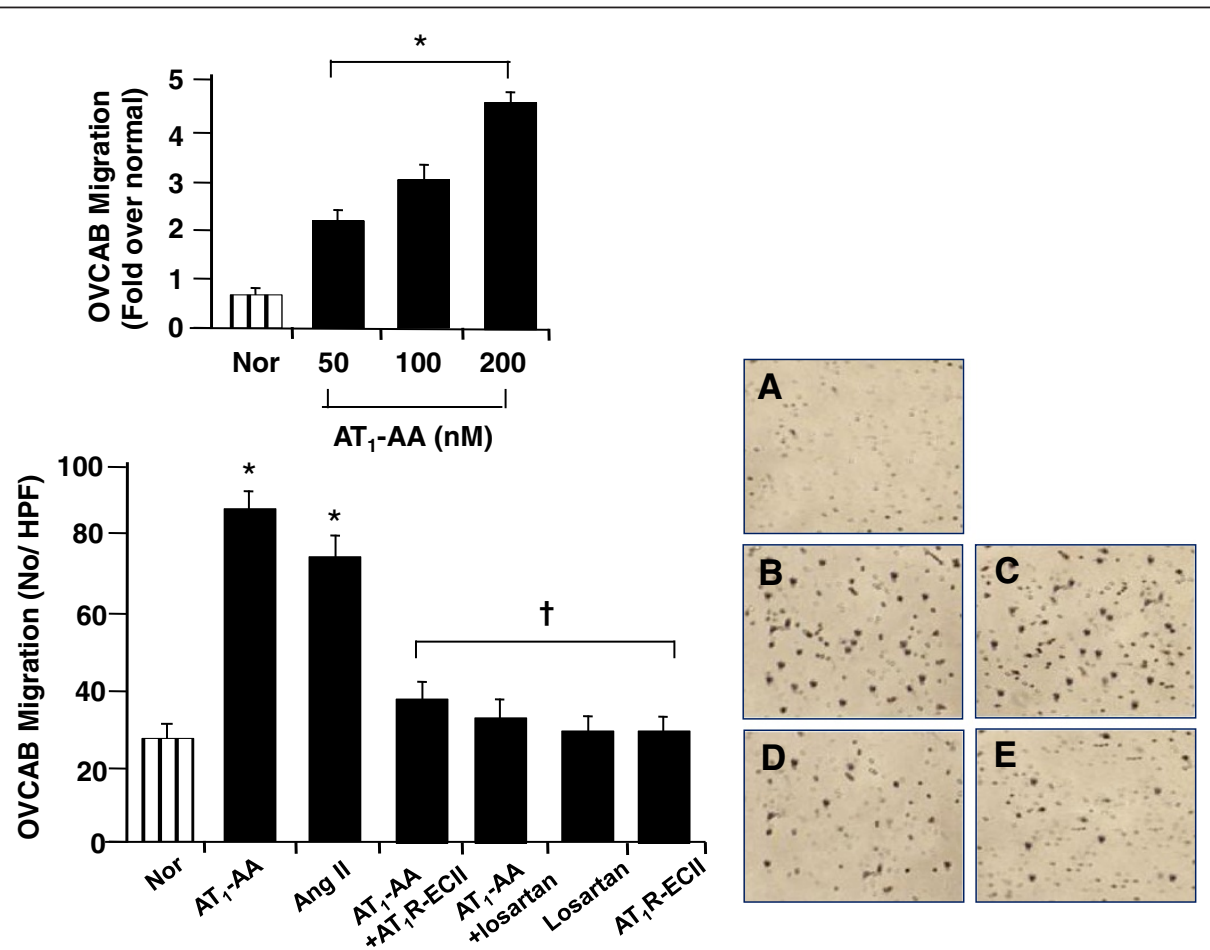

Figure 3 Effect of $\mathrm{AT}_{1}-\mathrm{AA}$ on migration of OVCAR3 cells. $\mathrm{AT}_{1}-\mathrm{AA}$ increased migration in a dose-dependent manner (top panel). Relative to the control (A), cell migration by AT 1 -AA was significantly enhanced (B), which is comparable to the level found in Ang II (C). Enhancement of migration by $\mathrm{AT}_{1}-\mathrm{AA}$ was blocked either by $\mathrm{AT}_{1}-\mathrm{AA}-\mathrm{ECII}(\mathbf{D})$ or losartan $(\mathbf{E})$. Values are mean $\pm \mathrm{SE} . \mathrm{n}=3$ for each group. ${ }^{*} \mathrm{p}<0.05 \mathrm{vs}$. saline control (Nor); $+\mathrm{P}<0.05$ vs. $A T_{1}-\mathrm{AA}$ and Ang II. HPF = high power field (x 400). 

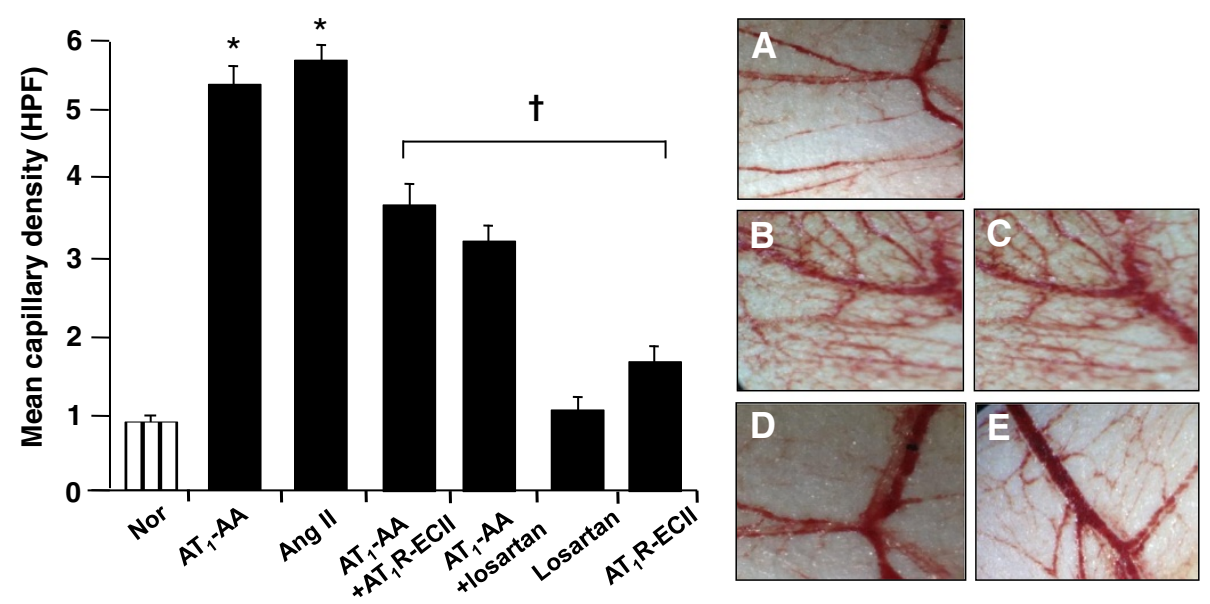

Figure 4 Effect of $\mathbf{A T}_{1}-\mathbf{A A}$ on angiogenesis of the CAM. Relative to the saline control $(\mathbf{A}), \mathrm{AT}_{1}-\mathrm{AA}$ significantly increased microvascular density of the CAM (B) to a comparable level as did by Ang II (C). Enhancement of microvascular density by $A T_{1}-A A$ was blocked either by AT 1 -AA-ECII (D) or Ang $\| \mathrm{AT}_{1}$ receptor antagonist, losartan (E). Values are mean $\pm \mathrm{SE} . \mathrm{n}=6$ for each group. ${ }^{*} \mathrm{p}<0.05$ vs. saline control (Nor); $+\mathrm{P}<0.05$ vs. $A T_{1}-A A$ and Ang II. HPF = high power field (x400).

significantly associated with tumor progression and poor prognosis [16-18]. Recent studies have shown that targeting inhibition of tumor angiogenesis through VEGF and its various signaling pathways is an effective therapy to suppress tumor growth and progression $[8,17]$. Our results showed that higher $\mathrm{AT}_{1}$-AA titer is positively correlated with VEGF level in advanced stages of EOC patients, consistent with previous findings showing a role of Ang II in cancer development through VEGF gene expression and secretion $[8,17]$.

Stimulation of $\mathrm{AT}_{1}$ receptor by Ang II has been reported to be involved in tumor progression in a number of cancers including EOC $[12,13]$. The postulated role of $\mathrm{AT}_{1}-\mathrm{AA}$ in cell migration and tumor spread led us to test if $\mathrm{AT}_{1}-\mathrm{AA}$ has direct stimulating effect on ovarian cell migration. We selected either autoantibodyneutralizing $\mathrm{AT}_{1}$-AA peptide, $\mathrm{AT}_{1} \mathrm{R}$-ECII as an inhibitor or selective $\mathrm{AT}_{1}$ receptor antagonist, losartan to test the direct effect of $\mathrm{AT}_{1}$-AA on cell migration and illustrate if this process is mediated by $\mathrm{AT}_{1}$ receptor [11]. We found that the migratory number of OVCAR3 cells was significantly increased in $\mathrm{AT}_{1}$-AA treated group, which was blocked either by $\mathrm{AT}_{1} \mathrm{R}$-ECII or losartan. These data suggested that $\mathrm{AT}_{1}$ - $\mathrm{AA}$ has direct effect on migration of ovarian cancer cells through activating $\mathrm{AT}_{1}$ receptor, consistent with a previous report showing that Ang IIinduced tumor cell invasion, angiogenesis and peritoneal dissemination are blocked by Ang $\mathrm{II} \mathrm{AT}_{1}$-receptor antagonist [19]. However, mechanistic studies are needed to further elucidate how $\mathrm{AT}_{1}-\mathrm{AA}$ activates the Ang II $\mathrm{AT}_{1}$ receptor. In line with our data, it has previously postulated that $\mathrm{AT}_{1}$ - $\mathrm{AA}$ may alter the structural conformation of Ang II $\mathrm{AT}_{1}$ receptor so that the receptor's ability binding to circulating Ang II is enhanced [12].
The CAM of chick embryo has widely been selected to study the morphological aspects of tumor angiogenesis and metastasis [20]. We chose the CAM of chick embryo as a test model to demonstrate angiogenic substances in our study because of its extensive vascularization and easy accessibility to investigate mechanisms of action of proangiogenic and antiangiogenic molecules [20]. We found that addition of $\mathrm{AT}_{1}-\mathrm{AA}$ at the same dose that causes OVCAR3 cell migration is effective in stimulating angiogenesis in the CAM, which was parallel with data showing elevation of VEGF in EOC patients. This increased microvascular density elicited by $\mathrm{AT}_{1}-\mathrm{AA}$ was comparable to the level as that in the Ang II group. Furthermore, we showed that the use of $\mathrm{AT}_{1} \mathrm{R}$-ECII or $\mathrm{AT}_{1}$ receptor blocker, losartan completely inhibits $\mathrm{AT}_{1}$-AA-induced angiogenesis of the CAM. These findings suggest that an enhancement of angiogenesis by $\mathrm{AT}_{1}$ - $\mathrm{AA}$ involves activation of Ang II $\mathrm{AT}_{1}$ receptor, thus selective Ang II $\mathrm{AT}_{1}$ blockade therapy could efficiently inhibit the $\mathrm{AT}_{1^{-}}$ AA-elicited angiogenesis under conditions exposed to $\mathrm{AT}_{1}-\mathrm{AA}$ as it has previously been reported [19].

There are several limitations to this study that need to be mentioned. First, although in vitro studies speculated the mechanisms responsible for the migration of cancer cells and angiogenesis through $\mathrm{AT}_{1}$ receptor, this study did not measure $\mathrm{AT}_{1}$ receptor expression to show whether such a change is associated with $\mathrm{AT}_{1}$-AA-mediated effects. Second, although a raised titer of $\mathrm{AT}_{1}-\mathrm{AA}$ was detected in EOC patients, the "cause-effect" relationship remains to be investigated. In this regard, it will be interesting to determine whether the $\mathrm{AT}_{1}$-AA titer falls in patients undergoing treatment. Third, the size of the study population was relatively small and limited only in the Asian patients. Therefore, future large-scale 
clinical trials will be necessary to further determine whether $\mathrm{AT}_{1}$-AA titer is also altered in EOC patients of different ethnicities.

\section{Conclusions}

In summary, we found that serum $\mathrm{AT}_{1}-\mathrm{AA}$ is elevated in higher proportion of EOC patients, which is associated with advanced stages and pathological grades of EOC, and appears to promote the ovarian call migration and angiogenesis through Ang II $\mathrm{AT}_{1}$ receptor. This study provides promising data showing that $\mathrm{AT}_{1}-\mathrm{AA}$ may play a significant role in development and progression of EOC, and might be considered as a potential therapeutic target in treatment of EOC patients.

\section{Abbreviations \\ $\mathrm{AT}_{1}$-AA: Agonistic autoantibodies against type-1 angiotensin-II receptor; Ang II: Angiotensin II; $A T_{1}$ : Angiotensin II type 1 receptor; $A T_{2}$ : Angiotensin II type II receptor; CAM: Chick embryo chorioallantoic membrane; EOC: Epithelial ovarian cancer; FIGO: International Federation of Gynecology and Obstetrics; OVCAR3: Human ovarian cancer cells; VEGF: Vascular endothelial growth factor.}

\section{Competing interests}

The authors declare that there is no conflict of interest that would prejudice the impartiality of this research work.

\section{Authors' contributions}

LS and HRL participated in research design, patient's investigation and manuscript writing. JY and SLZ carried out the in vitro experiments and data acquisition; HYX and TL performed data analysis and interpretation. All authors read and approved the final manuscript.

\section{Acknowledgements}

This study was supported by grants from the Science and Technology Plan Project of the Beijing Municipal Education Commission (KZ201110025023) and the National Natural Science Foundation of China (81070263).

Received: 3 March 2013 Accepted: 2 April 2013

Published: 5 April 2013

\section{References}

1. Jemal A, Siegel R, Xu JQ, Ward E: Cancer statistics, 2010. CA A Cancer J for Clinicians 2010, 60:277-300.

2. Robin SC, Randall TC, Amonstraong KA, Cji DS, Hoskins WJ: Ten-year followup of ovarian cancer patients after second-look laparotomy with negative findings. Obstet Gynecol 1999, 93:21-24.

3. Bristow RE, Tomacruz RS, Amonstrong DK, Trimable EL, Montz FJ: Survival effect of maximal cytoreductive surgery for advanced ovarian carcinoma during the platinum era: a meta-analysis. J Clin Oncol 2002, 20:1248-1399.

4. McFarlane SI, Kumar A, Sowers JR: Mechanisms by which angiotensinconverting enzyme inhibitors prevent diabetes and cardiovascular disease. Am J Cardiol 2003, 91:30H-37H.

5. Sanders PM, Russell ST, Tisdale MJ: Angiotensin II directly induces muscle protein catabolism through the ubiquitin-proteasome proteolytic pathway and may play a role in cancer cachexia. British J Cancer 2005, 93:425-434.

6. Egami K, Murohara T, Shimada T, Sasaki K, Shintani S, Sugaya T, Ishii M, Akagi T, Ikeda H, Matsuishi T, Imaizumi T: Role of host angiotensin II type I receptor in tumor angiogenesis and growth. J Clin Invest 2003, 112:67-75.

7. Yoshiji H, Kuriyama S, Kawata M, Yoshiji J, Ikenaka Y, Noguchi R, Nakatani T, Tsujinoue H, Fukui H: The angiotensin I converting enzyme inhibitor perindopril suppresses tumor growth and angiogenesis: possible role of the vascular endothelial growth factor. Clini Cancer Res 2001, 7:1073-1078.

8. Suganuma T, Ino K, Shibata K, Kajiyama H, Nagasaka T, Mizutani S, Kikkawa F: Functional expression of the angiotensin II type I receptor in human ovarian carcinoma cells and its blockade therapy resulting in suppression of tumor invasion, angiogenesis, and peritoneal dissemination. Clin Cancer Res 2005, 11:2686-2694.

9. Xia Y, Wen H, Bobst S, Day MC, Kellems RE: Maternal autoantibodies from preeclamptic patients activate angiotensin receptors on human trophoblast cells. J Soc Gynecol Invest 2003, 10:82-93.

10. Zhang SL, Zheng RH, Yang LH, Zhang X, Zou L, Yang XL, Bai KH, Song L, Tian J, Yang J, Liu HR: Angiotensin type I receptor autoantibody from preeclamptic patients induces human fetoplacental vasoconstriction. Cellular Physiology 2013, 228:142-148.

11. Thway TM, Shlykov SG, Day MC, Sanborn BM, Gilstrap LC, Xia Y, Kellems RE: Antibodies from preeclamptic patients stimulate increased intracellular $\mathrm{Ca}^{2+}$ mobilization through angiotensin receptor activation. Circulation 2004, 110:1612-1619.

12. Dechend R, Wiedt C, Muller DN, Ugele B, Brandes RP, Wallukat G, Park JK, Janke J, Barta P, Theuer J, Fiebeler A, Homuth V, Dietz R, Haller H, Kreuzer J, Luft FC: AT1 receptor agonistic antibodies from preeclamptic patients stimulate NADPH oxidase. Circulation 2003, 107:1632-1639.

13. Xia Y, Rami SM, Kellems RE: Potential roles of angiotensin receptoractivation autoantibody in the pathophysiology of preeclampsia. Hypertension 2007, 50:269-275.

14. Rossitto G, Regolisti G, Rossi E, Negro A, Nicoli D, Casali B, Toniato A, Caroccia B, Seccia MS, Walther T, Rossi GP: Elevation of angiotensin-II type 1 receptor autoantibodies titer in primary aldosteronism as a result of aldosterone-producing adenoma. Hypertension 2013, 61:526-533.

15. LaMarca B, Parrish M, Fournier Ray L, Murphy SR, Roberts L, Glover P Wallukat G, Wenzel K, Cockrell K, Martin JN, Ryan MJ, Dechend R: Hypertension in response to autoantibodies to the angiotensin II type I receptor (AT1-AA) in pregnant rats. Hypertension 2009, 54:905-909.

16. Kowanetz M, Ferrara N: Vascular endothelial growth factor signaling pathways: therapeutic perspective. Clini Cancer Res 2006, 12:5018-5022

17. Pang XF, Yi ZF, Zhang J, Lu BB, Sung BY, Qu WJ, Aggarwal BB, Liu MY: Celastrol suppresses angiogenesis-mediated tumor growth through inhibition of AKT/mammalian target of rapamycin pathway. Cancer Res 2010, 70:1951-1959.

18. Hicklin DJ, Ellis LM: Role of the vascular endothelial growth factor pathway in tumor growth and angiogenesis. J Clin Oncol 2005, 23:1011-1027.

19. Suganuma T, Ino K, Shibata K, Kajiyama H, Nagasaka T, Mizutan S, Kikkawa F: Functional expression of the angiotensin II type 1 receptor in human ovarian carcinoma cells and its blockade therapy resulting in suppression of tumor invasion, angiogenesis, and peritoneal dissemination. Clini Cancer Res 2005, 11:2686-2694.

20. Le noble F, Schreurs N, Van steaaten H, Slaaf D, Smith J, Rogg H, StruijkerBoudier $\mathrm{H}$ : Evidence for a novel angiotensin II receptor involved in angiogenesis in chick embryo chorioallantoic membrane. Am J Physiol Regul Integr Comp Physiol 1993, 33:R460-R465.

doi:10.1186/1757-2215-6-22

Cite this article as: Song et al.: Serum agonistic autoantibodies against type-1 angiotensin II receptor titer in patients with epithelial ovarian cancer: a potential role in tumor cell migration and angiogenesis. Journal of Ovarian Research 2013 6:22

\section{Submit your next manuscript to BioMed Central and take full advantage of:}

- Convenient online submission

- Thorough peer review

- No space constraints or color figure charges

- Immediate publication on acceptance

- Inclusion in PubMed, CAS, Scopus and Google Scholar

- Research which is freely available for redistribution 